Int. J. Environ. Res. Public Health 2008, 5(5) 436-440

International Journal of

Environmental Research and Public Health

ISSN 1661-7827

www.ijerph.org

(C) 2008 by MDPI

\title{
Bioavailability and Uptake of Lead by Coffeeweed (Sesbania exaltata Raf.)
}

\author{
Gloria Miller, Gregorio Begonia*, Maria Begonia and Jennifer Ntoni \\ Plant Physiology/Microbiology Laboratory, Department of Biology, P.O. Box 18540, College of Science, Engineering and \\ Technology, Jackson State University, 1000 Lynch Street, Jackson, Mississippi 39217, USA \\ ${ }^{*}$ Correspondence to Dr. Gregorio Begonia. Email: gregorio.begonia@jsums.edu
}

Received: 20 September 2008 / Accepted: 08 December 2008 / Published: 31 December 2008

\begin{abstract}
Lead $(\mathrm{Pb})$ is recognized as one of the most pervasive environmental health concerns in the industrialized world. While there has been a substantial reduction in the use of $\mathrm{Pb}$ in gasoline, water pipes, and $\mathrm{Pb}$-based residential paint, residual $\mathrm{Pb}$ from their use is still in the environment and constitutes an important source of $\mathrm{Pb}$ in the atmosphere, water, and soil. Soil acts as a sink for these anthropogenic sources of $\mathrm{Pb}$, accumulating the deposits over time in the upper $2-5 \mathrm{~cm}$ of undisturbed soil. Generally, $\mathrm{Pb}$ binds strongly to soil particles and renders a significant soil-metal fraction insoluble and largely unavailable for phytoremediation or plant uptake. A major objective of current phytoremediation research, therefore, is to induce desorption of $\mathrm{Pb}$ from the soil matrix into solution and increase the propensity for plant uptake. We hypothesized that the bioavailability of $\mathrm{Pb}$ for plant uptake can be increased through chelate amendments. To test this hypothesis, we mixed delta top soil and peat (2:1) and added lead nitrate $\left[\mathrm{Pb}\left(\mathrm{NO}_{3}\right)_{2}\right]$ to generate a Pb-contaminated soil concentration of $2000 \mathrm{mg} \mathrm{Pb} / \mathrm{kg}$ dry soil. After incubating the $\mathrm{Pb}$-spiked soil in a greenhouse for 6 weeks, Sesbania plants were grown in the soil and harvested at 6 , 8, and 10 weeks after emergence. Six days before each harvest, a chelating agent, ethylenediaminetetraacetic acid (EDTA) was applied to the root zone as an aqueous solution in a 1:1 ratio with the $\mathrm{Pb}$ concentration in the soil. Sequential extraction procedures were used to assess selective chemical fractions of $\mathrm{Pb}$ in the soil. Our results showed that a higher exchangeable fraction of $\mathrm{Pb}$ was available for plant uptake after chelate amendment compared to pre-chelate amendment. We also saw higher root and shoot $\mathrm{Pb}$ uptake after chelate amendment compared to pre-chelate amendment, especially at 10 weeks after emergence. Together, these results suggest that chelate amendments can promote the bioavailability of $\mathrm{Pb}$ in the soil and increased the propensity for uptake by plants into roots and shoots. Further, these results indicate that Sesbania exaltata can be grown under elevated $\mathrm{Pb}$ conditions and may be suitable as a potential crop rotation species for phytoextraction.
\end{abstract}

Keywords: Lead, Phytoextraction, Sequential extraction, Chelates,

\section{Introduction}

Geochemical forms of heavy metals in contaminated soils affect their solubility, which directly influence their availability to plants [1-3]. Although the total $\mathrm{Pb}$ concentration in many contaminated soils may be high, the bioavailable $\mathrm{Pb}$ fraction (water soluble and exchangeable) is usually very low due to the strong association of $\mathrm{Pb}$ with organic matter, Fe-Mn oxides, and clays, and precipitation as carbonates, hydroxides, and phosphates
[4]. Thus, increasing and maintaining $\mathrm{Pb}$ concentrations in soil solution are key factors in the phytoremediation of $\mathrm{Pb}$-contaminated soils. Ethylenediaminetetraacetic acid (EDTA), hydroxyethylenediaminetriacetic acid (HEDTA), and nitrilotriacetic acid (NTA) have been used in pot and field experiments to enhance heavy metal uptake by plants [5-9]. We have found in previous studies [10], using delta top soil and humus peat $(2: 1)$, that EDTA was the most effective in solubilizing soil bound $\mathrm{Pb}$ and that $\mathrm{Pb}$ concentrations in soil solution increased with extraction 
time and remained relatively constant 6 to 7 days after EDTA amendment. This indicated that soil $\mathrm{Pb}$ could be solubilized by EDTA in a short time and maintained at a high level afterwards.

Sequential extraction procedures were designed for the selective extraction of trace elements from operationally defined sediment solid fractions [11-13] and detailed information has been presented for the origin, mode of occurrence, biological and physicochemical availability, mobilization, and transport of trace metals $[11,14-16]$. Based on primary accumulation mechanisms in sediments, heavy metals can be classified into five categories [17]. Fraction 1, the exchangeable fraction is more likely to affect sorption-desorption processes. Fraction 2, the fraction that is bound to carbonates is the fraction that is most susceptible to changes in $\mathrm{pH}$. Fraction 3, the fraction that is bound to iron $(\mathrm{Fe})$ and manganese $(\mathrm{Mn})$ oxides generally acts as a scavenger for trace metals and is thermodynamically unstable under anoxic conditions [11]. Fraction 4, the fraction of metal that is bound to organic matter can be degraded under oxidizing conditions in natural waters, leading to a release of soluble trace metals. Fraction 5, generally known as the residual fraction is what is left after the first four fractions have been removed. It contains primary and secondary minerals which may hold trace metals within their crystal structure. These metals are not expected to be released under the conditions normally encountered in nature [11]. Sequential extraction methods are useful for evaluating the distribution of the metal within the soil matrix, and evaluating the remediation potential for the contaminant [18-20].

\section{Materials and Methods}

\section{Soil Preparation}

Delta top soil and humus peat were air-dried to $1-$ $3 \%$ moisture content for $3-4$ days under greenhouse conditions. Top soil and peat were cleaned of debris using a $1-\mathrm{cm}$ sieve. Soil was prepared by mixing sieved soil, and peat in a $2: 1$ volumetric proportion.

To prepare the lead-contaminated soil, approximately $550 \mathrm{~g}$ of the dry, sieved delta topsoil, peat mixture (2:1 $\mathrm{v} / \mathrm{v}$ ) were placed in a plastic zip loc bag and amended with $2000 \mathrm{mg} \mathrm{Pb} / \mathrm{kg}$ dry soil mixture using lead nitrate. Using preliminary gravimetric soil moisture determination data, a sufficient amount of deionized distilled water was added to each bag to adjust the soil moisture content to approximately $30 \%$ field capacity. The bags of soil were left to age on a laboratory bench in the greenhouse for 6 weeks. The bags were occasionally turned and mixed during the aging period to ensure thorough mixing.

\section{Plant Establishment and Maintenance}

After the 6-week incubation period, $550 \mathrm{~g}$ each of the $\mathrm{Pb}$-spiked soil were placed into designated $650 \mathrm{~mL}$ Deepot tubes (Stuewe and Sons, Inc., Corvallis, OR) and 6 pre-softened Sesbania seeds were planted and allowed to grow for 6,8 , and 10 weeks after emergence following the procedures previously described by Miller et al. [10]. Briefly, $550 \mathrm{~g}$ of aged, Pb-spiked soil were placed in 650 $\mathrm{mL}$ Deepot tubes that had been prepared by wrapping the holes on the sides and at the bottom with parafilm to prevent rapid water leaching and to allow aeration at the root zone. Seedlings were watered with $20 \mathrm{~mL}$ deionized distilled water or with a modified Hoagland's nutrient solution ( $\mathrm{pH}$ 6.5) which contained the following nutrients in $\mathrm{mM}: \mathrm{NH}_{4} \mathrm{NO}_{3}, 5 ; \mathrm{K}_{2} \mathrm{SO}_{4}, 1.25 ; \mathrm{CaCl}_{2} .2 \mathrm{H}_{2} \mathrm{O}, 2.0$; $\mathrm{MgSO}_{4} .7 \mathrm{H}_{2} \mathrm{O}, 0.5 ; \mathrm{K}_{2} \mathrm{HPO}_{4}, 0.15 ; \mathrm{CaSO}_{4} .2 \mathrm{H}_{2} \mathrm{O}, 6.0$; the following in $\mu \mathrm{M}: \mathrm{H}_{3} \mathrm{BO}_{3}, 2.3 ; \mathrm{MnSO}_{4} \cdot \mathrm{H}_{2} \mathrm{O}, 0.46$; $\mathrm{ZnSO}_{4} .7 \mathrm{H}_{2} \mathrm{O}, 0.6 ; \mathrm{CuSO}_{4} .5 \mathrm{H}_{2} \mathrm{O}, 0.15 ; \mathrm{NaMoO}_{4} .2 \mathrm{H}_{2} \mathrm{O}$, $0.10 ; \mathrm{CoCl}_{2} \cdot 6 \mathrm{H}_{2} \mathrm{O}, 10.0$; and $20 \mathrm{mg} / \mathrm{L} \mathrm{Fe}$ sequestrene. Emerged seedlings were thinned out to a desired population density of 2 plants per tube at 5 days after emergence. Ethylenediaminetetraacetic acid (1:1 ratio with the $\mathrm{Pb}$ ) was applied as $100 \mathrm{~mL}$ aqueous solution six days prior to each harvest. During harvest, shoots and roots were separated, and roots were washed with distilled water to remove any adhering debris, then oven-dried in a Thelco convection oven at approximately $75-80^{\circ} \mathrm{C}$ for at least 48 hours.

\section{Metal Extraction from Plant Tissues}

Dried samples were weighed and ground in a Wiley mill equipped with a $425 \mu \mathrm{m}$ (40-mesh) screen. Lead contents were extracted using EPA test methods 3050B, with slight modifications. Briefly, $40 \mathrm{ml}$ of $50 \%$ aqueous nitric acid were added to a $250 \mathrm{~mL}$ Erlenmeyer flask containing a representative sample of ground plant tissue. The acidified sample was heated to $35^{\circ} \mathrm{C}$, refluxed for 15 minutes without boiling, and then allowed to cool. Another $10 \mathrm{~mL}$ of $50 \%$ aqueous nitric acid were added and the sample was again heated and refluxed without boiling. To initiate the peroxide reaction, $2 \mathrm{~mL}$ of deionized distilled water and $3 \mathrm{~mL}$ of $30 \%$ hydrogen peroxide were added to the concentrated digestate and heated until effervescence subsided. Another $7 \mathrm{~mL}$ of $30 \%$ hydrogen peroxide were added continuously in $1 \mathrm{~mL}$ aliquots as the digestate was again heated. The digestate was heated until effervescence was minimal and its volume reduced to approximately $5 \mathrm{~mL}$. After cooling, the final digestate was diluted to approximately $15 \mathrm{~mL}$ with deionized water. The digestate was filtered through a filter paper (Whatman No. 1) and the final volume was adjusted to $25 \mathrm{~mL}$ with deionized, distilled water.

Lead concentrations were quantified using Perkin Elmer Optima 3300 DV Inductively Coupled PlasmaOptical Emission Spectrometry (ICP-OES) and expressed as $\mu \mathrm{g} \mathrm{Pb} / \mathrm{g}$ dry weight of plant tissue.

\section{Sequential Extraction of $\mathrm{Pb}$ from Soil Samples}

After each harvest $(6,8$, and 10 weeks after seedling emergence), $10 \mathrm{~g}$ of soil were removed from the center core of each tube, placed in a Ziploc specimen bag, and stored in 
the laboratory refrigerator $\left(\sim 4^{\circ} \mathrm{C}\right)$ for less than 3 days until further processing. The soil samples were dried at $75-80^{\circ} \mathrm{C}$ in a Thelco Convection oven. Each sample was ground into a fine homogeneous powder with a mortar and pestle and a 1 g sub-sample was placed into a $50 \mathrm{~mL}$ polypropylene centrifuge tube to minimize loss of solid material.

Between each successive extraction, and after centrifugation (Beckman Coulter Avanati-J-251 Centrifuge), the supernatant was aspirated into a sample tube by using a pipet and stored in the laboratory refrigerator $\left(\sim 4^{\circ} \mathrm{C}\right)$. The resulting residue was washed with $8 \mathrm{~mL}$ of deionized Millipore water, centrifuged 30 minutes, and the second supernatant (wash water) was discarded. The volume of rinse water used was kept to a minimum to avoid excessive solubilization of solid material, particularly organic matter. All reagents used in this study were of analytical grade or better. Deionized water used in preparing stock solutions and in each step of the extraction procedure was obtained from a Millipore system. All glasswares used for the experiments were previously soaked in $14 \% \mathrm{HNO}_{3}(\mathrm{v} / \mathrm{v})$ and rinsed with deionized distilled water.

\section{Fraction 1 - Exchangeable}

The soil sample along with $8 \mathrm{~mL}$ of $1 \mathrm{M}$ magnesium chloride $\left(\mathrm{MgCl}_{2}, \mathrm{pH}\right.$ 7.0) were agitated at room temperature for 1 hour, and then centrifuged at 12,000 rpm for 30 minutes. The supernatant was aspirated into a sample tube by using a pipette, and stored in the laboratory refrigerator at $\sim 4^{\circ} \mathrm{C}$ until further analyses.

\section{Fraction 2 - Carbonate}

Eight $\mathrm{mL}$ of $1 \mathrm{M}$ sodium acetate $(\mathrm{NaOAc})$ - adjusted to $\mathrm{pH} 5.0$ with acetic acid (HAc) were added to the centrifuge tube with the residue from the exchangeable fraction. The sample was agitated at room temperature for 5 hours, and then centrifuged at $12,000 \mathrm{rpm}$ for 30 minutes. The supernatant was aspirated into a sample tube by using a pipette, and stored in the laboratory refrigerator at $\sim 4{ }^{\circ} \mathrm{C}$ until further analyses.

\section{Fraction 3 - Fe-Mn Oxides}

Twenty $\mathrm{mL}$ of $0.04 \mathrm{M}$ hydroxylamine hydrochloride $\left(\mathrm{NH}_{4} \mathrm{OH} . \mathrm{HCl}\right)$ in $25 \%(\mathrm{v} / \mathrm{v}) \mathrm{HAc}$ were added to the centrifuge tube with the residue from the carbonate fraction. The sample was agitated occasionally at $\sim 96^{\circ} \mathrm{C}$ in a hot water bath for 6 hours. The sample was centrifuged at $12,000 \mathrm{rpm}$ for 30 minutes. The supernatant was aspirated into a sample tube by using a pipette, and stored in the laboratory refrigerator at $\sim 4^{\circ} \mathrm{C}$ until further analyses.

\section{Fraction 4 - Bound to Organic Matter}

Three $\mathrm{mL}$ of $0.02 \mathrm{M}$ nitric acid $\left(\mathrm{HNO}_{3}\right)$ and $5 \mathrm{~mL}$ of $30 \%$ hydrogen peroxide $\left(\mathrm{H}_{2} \mathrm{O}_{2}\right.$ adjusted to $\mathrm{pH} 2$ with $\mathrm{HNO}_{3}$ ) were added to the centrifuge tube with the residue from fraction 3 . The sample was heated to $\sim 85^{\circ} \mathrm{C}$ for 2 hours with occasional agitation. After cooling, $3 \mathrm{~mL}$ of $30 \% \mathrm{H}_{2} \mathrm{O}_{2}$ were added to the sample and again allowed to heat to $\sim 85^{\circ} \mathrm{C}$ for 3 hours with occasional agitation. After cooling, $5 \mathrm{~mL}$ of 3.2 ammonium acetate $\left(\mathrm{NH}_{4} \mathrm{OAc}\right)$ in $20 \%(\mathrm{v} / \mathrm{v}) \mathrm{HNO}_{3}$ were added. The sample was diluted to $20 \mathrm{~mL}$ and again agitated for 30 minutes at room temperature. The sample was centrifuged at 12,000 rpm for 30 minutes and the supernatant was aspirated into a sample tube by using a pipette, and stored in the laboratory refrigerator at $\sim 4^{\circ} \mathrm{C}$ until further analyses.

\section{Fraction 5 - Residual}

A corollary study was carried out to determine how we wanted to proceed to fraction 5. Thirty six soil samples were used to digest residue from fraction 4. Briefly, the residue from fraction 4 was digested with a 5:1 mixture of hydrofluoric and perchloric acids. The sediment was first digested in a platinum crucible with a solution of concentrated $\mathrm{HClO}_{4}(2 \mathrm{~mL})$ and $\mathrm{HF}(10 \mathrm{~mL})$ to near dryness; subsequently a second addition of $\mathrm{HClO}_{4}(1$ $\mathrm{mL})$ and $\mathrm{HF}(10 \mathrm{~mL})$ was made, and again the mixture was evaporated to near dryness. Finally, $\mathrm{HClO}_{4}(1 \mathrm{~mL})$ alone was added and the sample was evaporated until the appearance of white fumes. The residue was dissolved in $12 \mathrm{~N} \mathrm{HCl}$ and diluted to $25 \mathrm{~mL}$.

To quantify total soil $\mathrm{Pb}$ concentration, another $500 \mathrm{mg}$ soil sample was placed in a $250 \mathrm{~mL}$ Erlenmeyer flask, $40 \mathrm{~mL}$ of $50 \%$ nitric acid $\left(\mathrm{HNO}_{3}\right)$ were added, and the Nitric Acid Digestion procedures previously described above were followed. For fraction 5 our results revealed that there were no significant differences between the calculated residual fraction (total soil $\mathrm{Pb}$ less fractions 1 thru 4) and the digested residue of fraction 4 with hydrofluoric and perchloric acids (data not shown). Therefore, the residual fractions expressed in this experiment were calculated as the difference between total soil $\mathrm{Pb}$ concentration and the sum of the released fractions (fractions 1-4) [18]. Tessier and his colleagues [11] also reported that comparison of the sum of the metal concentrations in the individual fractions with the total metal concentrations to be in good agreement for the trace metals that they examined ( $\mathrm{Cd}, \mathrm{Co}, \mathrm{Cu}, \mathrm{Ni}, \mathrm{Pb}, \mathrm{Zn}, \mathrm{Fe}$, and $\mathrm{Mn})$. Lead concentrations were quantified using ICP-OES.

\section{Statistical Analysis}

Sesbania root, and shoot $\mathrm{Pb}$ uptake data consisted of 2 plants per tube, replicated 4 times. Sequential extraction samples consisted of 3 replicates per treatment. Data were analyzed using Statistical Analysis System (SAS V9). Treatment comparisons were done using Fisher's Protected Least Significant Difference (LSD) test. A probability of less than $5 \%(p<0.05)$ was considered to be statistically significant.

\section{Results and Discussion}

Root and shoot uptake analyses indicated that the greater percentage of $\mathrm{Pb}$ was sequestered in the roots, 
especially at 10 weeks after emergence. However, shoot $\mathrm{Pb}$ uptake increased after the addition of EDTA as compared to pre- EDTA amendment.

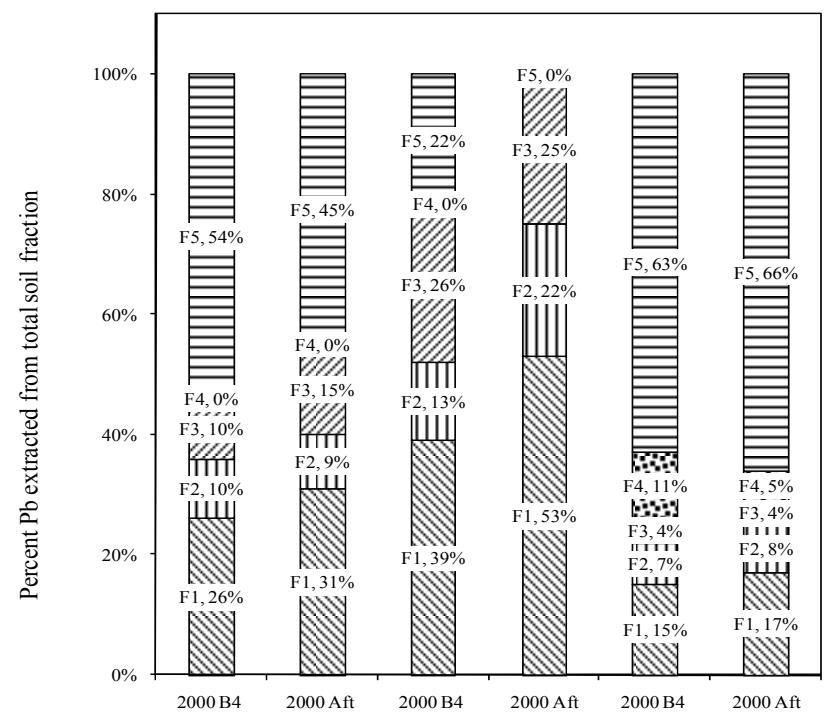

Figure 1: Lead partitioning in $\mathrm{Pb}$-spiked soil before and after chelate application. Lead-spiked soil was aged in a greenhouse for 6 weeks. Sesbania seeds were planted and allowed to grow for 6,8 , and 10 weeks. After each harvest, soil samples were collected and sequential extraction of $\mathrm{Pb}$ was performed. The operationally defined soil fractions were: (F1) exchangeable, (F2) carbonate, (F3) Fe-Manganese oxides, (F4) organic matter, and (F5) residual.

$$
\square 2000 \mathrm{ppm} / \mathrm{H} 2 \mathrm{O} \quad \square 2000 \mathrm{ppm} / \mathrm{EDTA}
$$

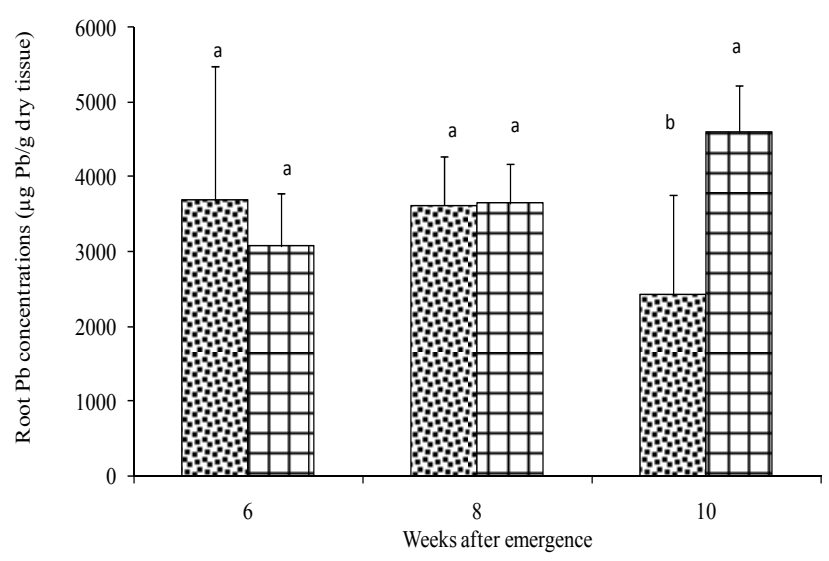

Figure 2: Effects of EDTA on root uptake of lead. Aqueous solutions were applied in a $1: 1$ ratio with $\mathrm{Pb}\left(\mathrm{NO}_{3}\right)_{2}$ at three different harvesting periods $(6,8$, and 10 weeks after seedling emergence). Sesbania plants were harvested 6 days after chelate application for each harvesting period. Values and error bars represent means and standard errors of 4 replicates. Treatments with common letters do not differ significantly from other treatments within the same time period. (Fisher's LSD $p<$ $0.05)$.

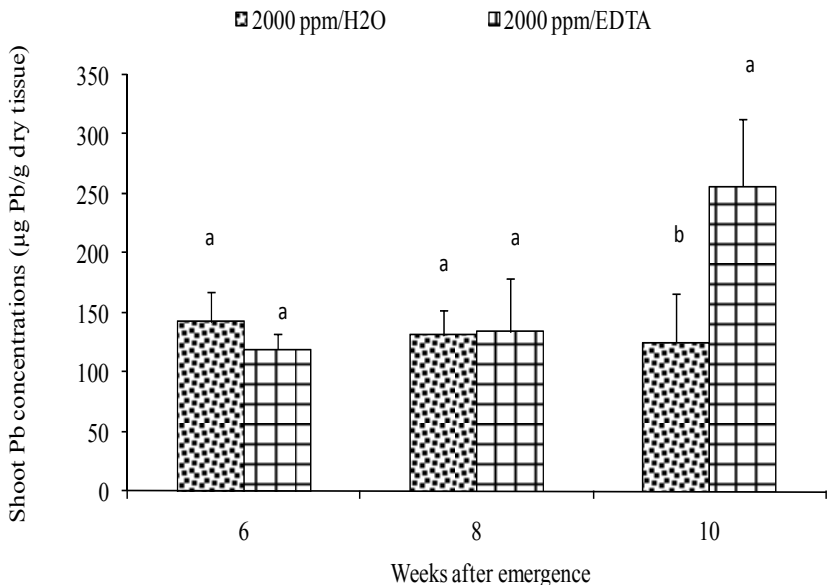

Figure 3: Effects of EDTA on shoot uptake of lead. Aqueous solutions were applied in a 1:1 ratio with $\mathrm{Pb}\left(\mathrm{NO}_{3}\right)_{2}$ at three different harvesting periods $(6,8$, and 10 weeks after seedling emergence). Sesbania plants were harvested 6 days after chelate application for each harvesting period. Values and error bars represent means and standard errors of 4 replicates. Treatments with common letters do not differ significantly from other treatments within the same time period. (Fisher's LSD $\mathrm{p}<0.05$ ).

Results of sequential chemical extraction (Fig. 1) showed that a greater percentage of $\mathrm{Pb}$ was concentrated in the residual fraction (F5) and the exchangeable fraction (F1). Only a small percentage of $\mathrm{Pb}$ was associated with the carbonate (F2), Fe-Manganese (F3) and organic matter (F4) fractions. Our analyses of root and shoot uptake showed that the greater percentage of $\mathrm{Pb}$ was found in root tissues (Fig. 2) compared to shoot tissues (Fig. 3). Shoot tissue uptake mirrored closely the uptake by roots, indicating that a proportionate amount of $\mathrm{Pb}$ was being translocated to the above-ground biomass. This observation was most remarkable at week 10 wherein we saw a dramatic increase in root and shoot uptake after the addition of EDTA. It has been shown in previous soil and hydroponics studies [5, 22] that $\mathrm{Pb}$ retention in roots was attributed to $\mathrm{Pb}$ binding to ion exchangeable sites on the cell wall, and extracellular precipitation of $\mathrm{Pb}$ carbonates that are deposited in the cell wall. It can be reasoned that EDTA effectively prevented cell wall retention in the roots, thereby making it more available for translocation to the shoot.

Soil-metal interaction by sorption, precipitation and complexation processes, and differences between plant species in metal uptake efficiency, transport, and susceptibility make a general prediction of soil metal bioavailability and risks of plant metal toxicity difficult [21]. Moreover, the tight binding characteristic of $\mathrm{Pb}$ to soils and plant materials makes a significant portion of $\mathrm{Pb}$ unavailable for root uptake by plants. In a sequential extraction procedure for the speciation of particulate trace metals, Tessier et al. [11] found that the exchangeable fraction of $\mathrm{Pb}$ (Fraction 1) is readily available for sorption-desorption processes, Fraction 2 is more likely to be susceptible to changes of $\mathrm{pH}$, Fraction 3 (iron [Fe] and manganese [Mn] oxides), and Fraction 4, (organic matter) 
have a scavenging action for trace metals that is far out of proportion to their ( $\mathrm{Fe}, \mathrm{Mn}$ and organic matter) own concentrations, and should be considered when estimating the bio-availability of a particular metal. Lead, may be mostly concentrated in the residual fraction, and is not expected to be released in solution over a reasonable time span under the conditions normally encountered in nature, and is therefore not available for uptake by the plant.

\section{Conclusions}

This experiment demonstrated that as a $\mathrm{Pb}-$ contaminated soil ages; the metal may become less available in Fraction 1, and partitions more into Fraction 5 , (the residual fraction). Because $\mathrm{Pb}$-contaminated soils may be dynamic, sequential extraction methods may be useful for evaluating the distribution of the metal within the soil matrix. In essence, the sequential extraction procedure examines the metal's geochemical association with the soil under various soil treatments, and provides useful information for predicting the environmental conditions under which the lead is likely to be released or made bioavailable for plant uptake [17]. Therefore, the sequential extraction methods may be suitable for an evaluation of remediation potential and/or success for contaminated soils [18]. Further, we concluded that EDTA can be applied to selected Pb-contaminated soils in a time-efficient manner so that plants can be harvested during their peak phytoextractive period, thereby reducing the risk of water pollution due to chelates and/or chelatemetal complexes migrating from the soil.

\section{References}

1. Davis, A.; Drexler, J. W.; Ruby, M. V.; Nicholson, A. Micromineralogy of mine wastes in relation to lead bioavailability. Environ. Sci. Technol. 1993, 27, $1415-1425$.

2. Zhang, M.; Alva, A. K.; Li, Y. C.; Calvert, D. V. Chemical association of $\mathrm{Cu}, \mathrm{Zn}, \mathrm{Mn}$, and $\mathrm{Pb}$ in selected sandy citrus soils. Soil Sci 1997, 162, 181 - 188.

3. Gray, C. W.; McLaren, R. G.; Roberts, A. H. C.; Condron, L. M.: Solubility, sorption and desorption of native added cadmium in relation to properties of soils in New Zealand. Eur. J. Soil Sci. 1999, 50, 127 - 137.

4. McBride, M. B. Environmental chemistry of soils. Oxford University Press: 1994.

5. Blaylock, M. J.; Salt, D. E.; Dushenkov, S.; Zakharova, O.; Gussman, C.; Kapulnik, Y.; Ensley, B. D.; Raskin, I. Enhanced accumulation of $\mathrm{Pb}$ in Indian mustard by soil-applied chelating agents. Environ. Sci. Technol. 1997, 31, (3), 860-865.

6. Huang, J. W.; Chen, J.; Berti, W. R.; Cunningham, S. D. Phytoremediation of lead- contaminated soils: Role of synthetic chelates in lead phytoextraction. Environ. Sci. Technol. 1997, 31, (3), 800-805.

7. Huang, J. W.; Cunningham, S. D.: Lead phytoextraction: Species variation in lead uptake and translocation. New Phytologist 1996, 134, 75 - 84.
8. Ebbs, S. D.; Kochian, L. V.: Phytoextraction of zinc by oat (Avena sativa), barley (Hordeum vulgare) and Indian mustard (Brassica juncea). Environ. Sci. Technol. 1998, 32, 802 - 806.

9. Kayser, A.; Wenger, K.; Keller, A.; Attinger, W.; Felix, H. R.; Gupta, S. K.; Schulin, R.: Enhancement of phytoextraction of $\mathrm{Zn}, \mathrm{Cd}$, and $\mathrm{Cu}$ from calcareous soil: The use of NTA and sulfur amendments. Environ. Sci. Technol. 2000, 34, 1778 - 1783.

10. Miller, G.; Begonia, G.; Begonia, M.; Ntoni, J.; Hundley, O.: Assessment of the efficacy of chelateassisted phytoextraction of lead by coffeeweed (Sesbania exaltata Raf). International Journal Environ. Res. Public Health 2008, 428-435.

11. Tessier, A.; Campbell, P. G. C.; Bisson, M.: Sequential extraction procedure for the speciation of particulate traces metals. Analytical Chemistry 1979, $51,(7), 844-851$.

12. Salomons, W.; Förstner, U.: Trace metal analysis on polluted sediments. Part II. Evaluation of environmental impact. Environ Technol Lett 1980, 1, $506-517$.

13. Pueyo, M.; Sastre, J.; Hernández, E.; Vidal, M.; López-Sánchez, J. F.; Rauret, G. Heavy metals in the environment. J Environ Qual 2003, 32, 2054 - 2066.

14. Chaudhuri, D.; Tripathy, S.; Powell, H. V. A.; Hart, B. R.: Relationship of chemical fractions of heavy metals with microial and enzyme activities in sludge and ash-amended acid lateritic soil from India. Environ. Geol. 2003, 44, 419 - 432.

15. 15. Kaasalainen, M.; Yli-Halla, M. Use of sequential extraction to assess metal partitioning in soils. Environ. Pollut. 2003, 126, 225 - 233.

16. McLaren, R. G.; Clucas, L. M.: Fractionation of copper, nickel, and zinc in metal-spiked sewage sludge. J Environ Qual 2001, 30, 1968 - 1975.

17. Ma, L. Q.; Rao, G. N.: Chemical fractionation of cadmium, copper, nickel and zinc in contaminated soils. J Environ Qual 1997, 26, 259 - 264.

18. Tlustoš, P.; Szárková, J.; Stárková, A.; Pavlǐková, D. A comparison of sequential extraction procedures for fractionation of arsenic, cadmium, lead, and zinc in soil. Central European Journal of Chemistry 2005, 3, (4), 830 - 851.

19. Lim, T. T.; Tay, J. H.; Wang, J. Y. Chelating-agentenhanced heavy metal extraction from a contaminated acidic soil. J. Environ. Eng. 2004, 130, 59 - 66.

20. Filgueiras, A. V.; Lavilla, I.; Vendicho, C. Chemical sequential extraction for metal partitioning in environmental solid samples. J. Environ. Monit., 2002, 4, 823 - 857.

21. Keltjens, W. G.; van Beusichem, M. L.: Phytochelatins as biomarkers for heavy metal toxicity in maize: Single metal effects of copper and cadmium. J. Plant Nutr. 1998, 21, (4), 635 - 648.

22. Dushenkov, V.; Kumar, N. P. B. A.; Motto, H.; Raskin, I. Rhizofiltration - the use of plants to remove heavy metals from aqueous streams. Environ. Sci. Technol. 1995, 29, 1239-1245. 